RELASI

Jurnal Ekonomi

\title{
Pengaruh Lingkungan Kerja Dan Pengembangan Karyawan Terhadap Kepuasan Kerja Karyawan Pada Bank BTN (Persero) Cabang Karangasem
}

\author{
Megawati \\ Universtas Indraprasta PGRI Jakarta \\ Email : megawati090368@gmail.com
}

\begin{abstract}
The research is conducted in order to analyze the influence of working environment, employee development toward work satisfaction in BTN Bank (Persero) Karangasem to obtain of more deep influence of employee development, working environment toward worked satisfaction in BTN Bank (Persero) Karangasem. Data is analyzed constructively by using the technique analyze the simple regression and multiple regression analysis. Research location is the employee in BTN Bank (Perswero) Karangasem The method of this research is simple random sampling, that taken 55 Operational Division employee at Transaction Process Division, Loan Administration Division, and General Administration Division, while data collecting by using questionnaire and cultivated using SPSS 19.0. The result of t test for working environment is 2.123, and the signification is 0.038. This shows that there is an effect between working environment toward job satisfaction. The result of t test for employee development is -2.160 , and the signification is 0.035 This shows that there is an effect between employee development toward job satisfaction. The result of $F$ test is 5.798, and the signification is 0.005. This shows that there is an effect between working environment and employee development toward job satisfaction. The result of $R 2$ is 0.182 or $18,2 \%$. It means Job Satisfaction is affected by working environment and employee development as much as 18,2\%.
\end{abstract}

Keywords: working environment, employee development, job satisfaction

\section{Pendahuluan}

Globalisasi mempunyai kaitan erat dengan dunia internet, pengguna internet terus mengalami peningkatan baik secara global maupun di Indonesia . Menurut hasil survey yang dilakukan oleh asosiasi penyelenggara jaringan internet indonesia (APJII) diperoleh data sebagai berikut : pada tahun 2017 pengguna internet mencapai 143,26 juta jiwa atau setara dengan 54,68\% dari total jumlah penduduk Indonesia. Jumlah tersebut menunjukkan kenaikan sebesar 10,56 juta jiwa dari hasil survey pada tahun 2016. Dari data tersebut dapat dikatakan lebih dari setengah populasi warga negara Indonesia telah mengenal internet. 
Pemakai internet di Indonesia yang semakin meningkat dapat dijadikan tolak ukur sebuah peluang bisnis yang menjanjikan pada bidang E-commerce. Berkaca dari data Bank Indonesia yang menyebutkan bahwa nilai transaksi e-commerce di Indonesia pada tahun 2016 mencapai Rp. 75 Triliun. E-commerce atau kerap kali disebut belanja online merupakan proses dimana konsumen membeli produk atau jasa melalui sistem elektronik seperti internet, televisi atau jaringan komputer lainnya. Konsumen berubah kebiasaan dan budaya dalam membeli, tidak harus datang ke toko, toko tidak hanya secara fisik, pasar online bisa dimanfaatkan. Ditengah kepopuleran sistem belanja online atau E-commerce masih ditemukan berbagai macam kendala yang hendaknya segera diupayakan penyelesaiannya antara lain sedikitnya konsumen online yang tertarik pada beberapa penawaran online yang ada, serta kurangnya pengetahuan tentang adanya standar teknologi untuk mekanisme pembayaran yang aman dan kesenjangan keuntungan bisnis meskipun pemerintah telah mengantisipasi dengan mengeluarkan Paket Kebijakan Ekonomi Jilid 14 tentang peta jalan pengembangan e-commerce yang meliputi pendanaan, perpajakan, perlindungan konsumen, pendidikan SDM, logistik, infrastruktur komunikasi, keamanan di internet dan pembentukan manajemen pelaksanaan. Dalam kegiatan jual beli secara online terdapat suatu wadah bagi penjual yang sering disebut sebagai platform. Kemudahan arus informasi yang ditunjang dengan internet pada platform tersebut membuat konsumen dapat membeli segala kebutuhan. Beberapa faktor yang dipertimbangkan konsumen untuk memutuskan melakukan pembelian online diantaranya adalah harga, kualitas produk , faktor kemudahaan penggunaan website untuk transaksi, keamanan dalam bertransaksi, kualitas informasi serta faktor kepercayaan . Mahasiswa sebagai kalangan yang hampir tidak dapat dipisahkan dengan internet tentunya menjadi pengguna mayoritas layanan berbasis teknologi seperti belanja online (daring), produk-produk yang dibeli oleh kalangan mahasiswa tentunya berbagai macam jenisnya dapat berupa barang maupun jasa. Mahasiswa STIE Mandala Jember sendiri terdiri dari berbagai macam kalangan dan memiliki status sosial dan ekonomi yang berbeda-beda. Perbedaan status sosial dan ekonomi ini juga dapat memiliki pengaruh saat mahasiswa melakukan proses pembelian secara online (daring). Berdasarkan survey yang dilakukan perusahaan riset MARS secara independen mengenai E-commerce pada berbagai macam kalangan sosial ekonomi dan berdasarkan usia, menyimpulkan bahwa kelompok umur yang melakukan belanja online 
paling besar adalah kelompok umur 30-44 tahun, tetapi kelompok usia 13-21 tahun dan 2229 tahun jika di jumlah memiliki total yang lebih besar. Mahasiswa STIE Mandala Jember termasuk pada kedua kelompok tersebut, bahkan pada kelompok usia 30-44 tahun juga terdapat bagian dari mahasiswa contohnya untuk program pasca sarjana. Dari sini bisa disimpulkan bahwa mahasiswa STIE Mandala termasuk pengguna sistem e-commerce.

Ranganathan \& Sanjeev (2007) menyimpulkan bahwa kenyamanan, kemudahan, harga dan penghematan waktu menjadi faktor yang dipertimbangkan dalam pembelian online. Faktor lain yang juga menjadi pertimbangan adalah kualitas informasi, kualitas informasi didefinisikan sebagai persepsi pelanggan terhadap kualitas informasi tentang produk atau layanan yang disediakan oleh website .Semakin berkualitas informasi, semakin lengkap informasi yang diberikan maka akan semakin tinggi minat pembeli online untuk membeli suatu produk. Wahyu Husodo (2015), Dala Noor Iftikhar dan Rizal Hadi Magnadi (2017) menyimpulkan bahwa kepercayaan , kemudahan harga dan kualitas informasi berpengaruh positif dan signifikan terhadap keputusan pembelian secara online. Faktor keamanan juga menjadi pertimbangan . Arasu \& Viswanathan (2011),Ilham Tugiono (2016), Diyan Firmansyah (2017) melalui studi yang dilakukan menyimpulkan bahwa faktor keamanan memiliki pengaruh terhadap penjualan online. Berdasarkan uraian diatas rumusan masalah dalam penelitian ini adalah apakah harga, kemudahan, kualitas informasi, keamanan dan kepercayaan berpengaruh baik secara parsial maupun simultan terhadap keputusan pembelian online pada mahasiswa STIE Mandala Jember. Tujuan dari penelitian untuk mengetahui adanya pengaruh harga, kemudahan, kualitas informasi, keamanan dan kepercayaan baik secara parsial maupun simultan terhadap keputusan pembelian online pada mahasiswa STIE Mandala Jember. Penelitian ini penting dilakukan karena diharapkan memberi manfaat baik bagi peneliti, maupun bagi perusahaan yang bergerak di ECommerce. Bagi peneliti untuk menambah wawasan dan ilmu pengetahuan yang berhubungan dengan manajemen pemasaran, sedangkan bagi perusahaan bisa digunakan sebagai masukan dalam membuat kebijakan dan strategi yang mendorong pembelian secara online.

\section{Tinjauan Pustaka}

\subsection{Penelitian Terdahulu}


Beberapa penelitian terdahulu yang dijadikan rujukan dalam penelitian ini diantaranya adalah, Kartika Ayuningtyas (2018)menuliskan bahwa secara simultan Kepercayaan, Kemudahan dan Kualitas Informasi berpengaruh terhadap Keputusan Pembelian Daring. Kemudahan, kualitas informasi berpengaruh signifikan sedangkan kepercayaan tidak signifikan . Sukawati (2018) menyimpulkan secara simultan kepercayaan, harga dan kualitas produk berpengaruh secara signifikan terhadap pembelian melalui internet .Sedangkan secara parsial kualitas produk tidak berpengaruh secara signifikan sedangkan variabel lainnya berpengaruh secara signifikan terhadap pembelian melalui internet.Ismail Hidayat dan Rois Arifin (2017) menyimpulkan bahwa secara simultan semua variabel Kepercayaan, kemudahan, harga dan Kualitas Informasi mempunyai pengaruh yang signifikan terhadap keputusan pembelian, sedangkan secara parsial untuk variabel harga dan kualitas informasi tidak berpengaruh secara signifikan terhadap keputusan pembelian secara secara online. Variabel kepercayaan dan kemudahan mempunyai pengaruh yang signifikan. Diyan FirmanSyah (2017) menyimpulkan secara bersama sama (simultan) ada pengaruh positif dan signifikan antara Persepsi Keamanan dan Privasi terhadap kepuasan dan kepercayaan Konsumen Online. Secara individu (parsial) masing masing variabel terbukti berpengaruh positif dan signifikan. Yeni Yuniarti (2016). Menyimpulkan secara simultan semua variable yaitu kualitas produk, harga, dan kepercayaan mempunyai pengaruh yang signifikan terhadap keputusan pembelian secara online, sedangkan secara parsial yang berbeda adalah variabel harga yaitu harga mempunyai pengaruh yang positif tetapi tidak signifikan. Ratna Dwi Jayanti (2015) dalam penelitiannya menyimpulkan variabel harga tidak berpengaruh signifikan terhadap keputusan pembelian secara online, Kepercayaan berpengaruh secara signifikan terhadap pembelian secara online. Secara bersama sama variabel harga dan kepercayaan mempunyai pengaruh yang signifikan.

Wahyu Husodo (2015) menyimpulkan bahwa variabel kepercayaan, kemudahan, harga dan kualitas informasi berpengaruh signifikan terhadap keputusan pembelian secara online, variabel harga yang mempunyai pengaruh paling dominan. Ananda cahya hardiawan (2013) menyimpulkan bahwa kepercayaan, kemudahan dan kualitas informasi berpengaruh positif dan signifikan terhadap keputusan pembelian. Faktor yang pengaruhnya dominan adalah kepercayaan. 


\subsection{Telaah Pustaka}

\subsubsection{Pemasaran}

Menurut Kotler (2006:9) pemasaran adalah suatu proses sosial pada sebuah individu atau dalam suatu kelompok guna memperoleh hal-hal yang diinginkan serta dibutuhkan dengan cara menciptakan, menawar, dan menukarkan produk yang memiliki nilai dengan pihak lain. Menurut Stanton (1991:5) Marketing is a total sistem of business activities designed to plan, price, promote and distribute want-satisfying product to target markets to achieve organization.

Berdasar pendapat dua ahli diatas terdapat kesamaan yaitu terdapatnya kebutuhan dari dua belah pihak dan kedua belah pihak memiliki peranan tersendiri dalam melakukan fungsinya baik dalam skala individu maupun dalam skala sebuah kelompok atau organisasi. Seiring dengan perkembangan ilmu perekonomian khususnya ilmu manajemen bidang pemasaran juga berkembang dengan pesat seiring dengan perkembangan teknologi yang terjadi di dunia. Beberapa teknologi telah diciptakan untuk memudahkan kedua belah pihak yang terlibat dalam kegiatan pemasaran ini agar tujuan tercapai dengan efektif dan efisien, salah satu contoh penemuan dibidang teknologi dalam bidang pemasaran adalah pemasaran yang berbasis internet dimana setiap proses pemasaran tersebut dilakukan dengan dukungan internet guna menunjang terjadinya proses pertukaran produk. E-commerce merupakan salah satu contoh dari pemanfaatan teknologi internet dalam bidang pemasaran.

\subsubsection{E-commerce}

E-commerce merupakan proses dimana konsumen membeli suatu produk di internet adalah penjualan, pembelian, pemasaran barang dan jasa melalui sistem elektronik seperti handphone, televisi, dan jaringan komputer. Dalam E-commerce kegiatan yang terjadi misalnya transfer dana-dana secara elektronik, data secara elektronik, sistem manajemen penyimpanan otomatis di internet maupun teknologi lainnya, hingga sistem pengumpulan data secara otomatis. Beberapa faktor yang memengaruhi pembelian secara online diantaranya adalah harga, kemudahan, kualitas informasi, keamanan dan kepercayaan.

\subsubsection{Harga}

Keputusan-keputusan penentuan harga memengaruhi penjualan yang dicapai maupun keuntungan yang didapatkan oleh perusahaan. Menurut McCarty (1983:414) 
harga (price) adalah apa yang dibebankan untuk 'sesuatu'. Tjiptono (2011:151) menyebutkan bahwa harga merupakan satu-satunya pemasaran yang memberikan pemasukan atau pendapatan bagi perusahaan.

\subsubsection{Kemudahan}

Menurut Hartono dalam Luthfiya (2014:32). Kemudahan didefinisikan sebagai sejauh mana seseorang percaya bahwa menggunakan suatu teknologi akan bebas dari usaha . Faktor kemudahan akan berdampak pada perilaku yang ditunjukkan oleh konsumen, semakin mudah dalam transaksi pembelian akan mendorong orang untuk lebih banyak melakukan pembelian.

\subsubsection{Kualitas informasi}

Perkembangan arus informasi kini telah membawa perubahan pada tiap-tiap individu maupun kelompok misalnya dalam kegiatan belanja online. Dalam proses belanja online pencarian informasi dimulai pada saat konsumen menganggap bahwa kebutuhan tersebut dapat dipenuhi dengan membeli dan mengkonsumsi suatu produk. Informasi yang ditawarkan harus berguna dan harus relevan dengan kondisi aktual dalam memprediksi kualitas serta kegunaan produk dan jasa. Selain itu informasi juga harus selalu up-to-date untuk memuaskan kebutuhan konsumen akan informasi produk yang diinginkan. Kualitas informasi yang baik juga dapat memberikan persepsi terhadap produk yang ditawarkan pada sebuah website

\subsubsection{Keamanan}

Menurut Park \& Kim (2006:81) keamanan atau security adalah kemampuan toko online dalam melakukan pengontrolan dan penjagaan keamanan atas transaksi data. Jaminan keamanan inilah yang berperan penting dalam pembentukan kepercayaan seperti halnya penyalahgunaan informasi pribadi untuk kepentingan tertentu.

\subsubsection{Kepercayaan}

Morman dalam (Antarwiyati, 2010:5) mendefinisikan kepercayaan (trust) sebagai kemauan untuk bergantung pada penjual yang dapat dipercaya, dalam transaksi secara online, kepercayaan muncul ketika mereka yang terlibat telah mendapat kepastian dari pihak lainnya, serta mau dan bisa memberikan kewajibannya. Hambatan yang paling signifikan dalam jangka panjang terhadap keberhasilan internet sebagai media komersil pada pasar adalah kurangnya kepercayaan konsumen terhadap internet dan penjual penjual 
online didalamnya (Jarvenpaa et al. 2000:50).

\subsubsection{Keputusan Pembelian}

Menurut Kotler dan Armstrong (2008: 227) keputusan pembelian adalah tahap proses keputusan saat konsumen secara aktual melakukan pembelian produk. Proses keputusan pembelian menurut Kotler (2009:234) terdiri dari lima tahap, yaitu: pengenalan kebutuhan, pencarian informasi, evaluasi alternatif, keputusan pembelian, paska pembelian.

\subsubsection{Keputusan Pembelian Online (Daring)}

Dengan kemudahan akses internet pada era globalisasi ini tidak hanya informasi yang menyebar secara online transaksi juga terjadi secara online salah satu bentuk transaksi secara online adalah belanja online yang kini telah menjadi sebuah fenomena yang tidak dapat dihindari selain karena kepraktisan dan efisiensi waktu yang dibutuhkan. Belanja secara online memberikan trend baru kepada berbagai macam kalangan tidak terkecuali kalangan muda-mudi yang kerap kali disebut dengan milenial. Belanja online adalah bentuk perdagangan elektronik yang digunaan pada transaksi Business to Bussiness (B2B) dan Business to Consumer (B2C).

Menurut Devaraj seperti dituliskan oleh Hardiawan (2013) keputusan pembelian secara online dipengaruhi oleh :

a. Efisiensi untuk pencarian (waktu cepat,mudah dalam penggunaan, dan usaha pencarian mudah

b. Value (harga bersaing dan kualitas baik)

c. Interaksi (informasi, keamanan, load time dan navigasi.)

2.2.9 Kerangka Konseptual dan Hipotesis :

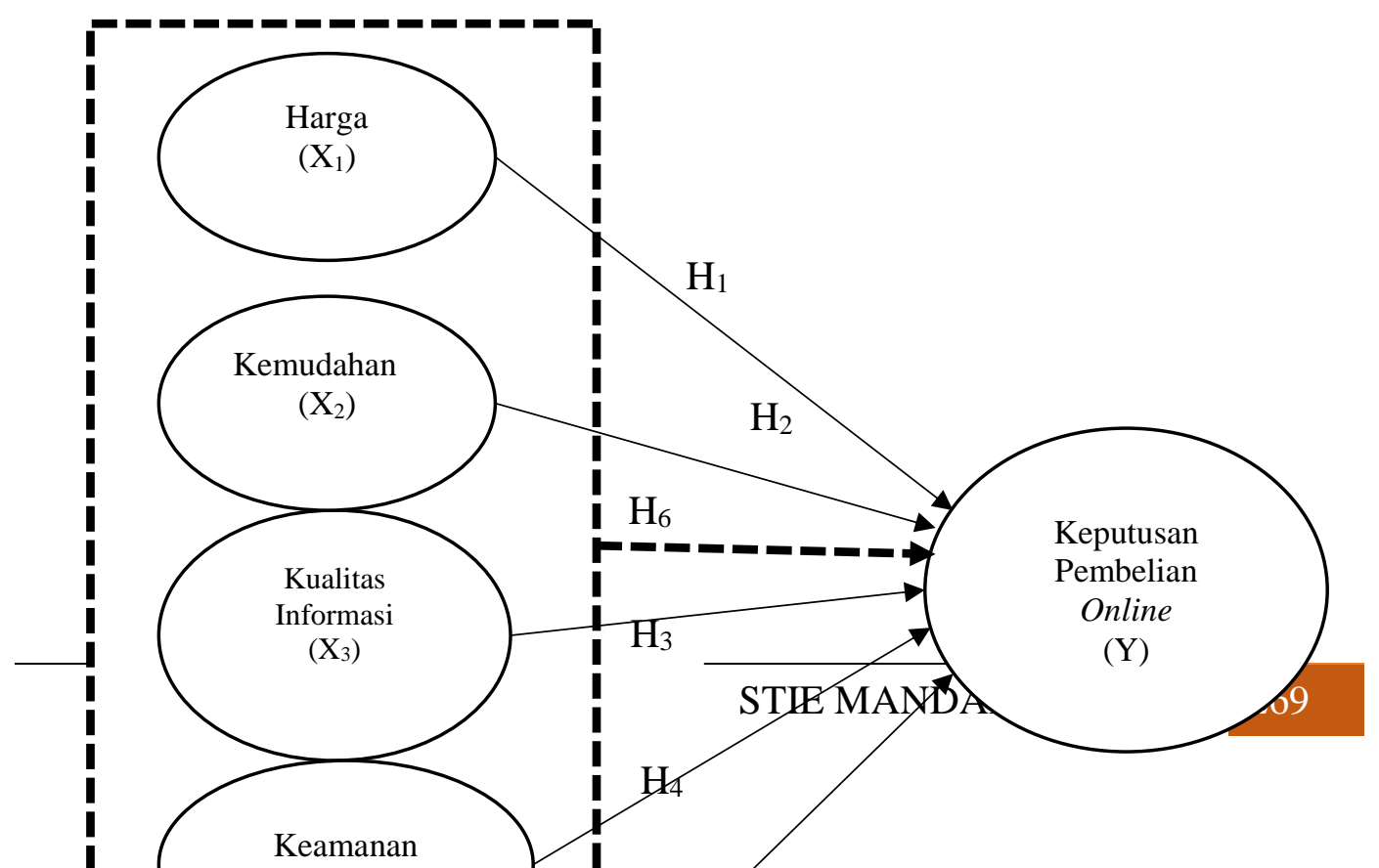


Keterangan Gambar :

menunjukkan pengaruh secara simultan

Menunjukkan pengaruh secara parsial

Gambar 1. Kerangka konseptual

Hipotesis yang bisa dirumuskan dalam penelitian ini adalah :

H1: Diduga harga berpengaruh secara parsia terhadap keputusan pembelian secara online

H2 : Diduga kemudahan berpengaruh secara parsial terhadap keputusan pembelian secara online

H3 : Diduga kualitas informasi berpengaruh secara parsial terhadap meputusan pembelian secara online

H4 : Diduga keamanan berpengaruh secara parsia terhadap keputusan pembelian secara online

H5 : Diduga kepercayaan berpengaruh secara parsial terhadap meputusan pembelian secara online

H6 : Diduga harga, kemudahan, kualitas informasi, keamanan dan kepercayaan berpengaruh secara simultan terhadap keputusan pembelian secara online

\section{Metode Penelitian}

Penelitian ini dilaksanakan di STIE Mandala Jember dengan obyek penelitian mahasiswa STIE Mandala. Populasi pada penelitian ini adalah Mahasiswa STIE Mandala Jember. Jumlah sampel yang diambil sebanyak100 responden, dengan teknik pengambilan sampel menggunakan teknik nonprobability sampling, dan metode pengambilan menggunakan Purposive sampling, yaitu teknik pengambilan sampel dengan pertimbangan 
tertentu (Sugiyono, 2015:85). Pertimbangan tertentu itu meliputi : (a) responden pernah melakukan pembelian online;(b) responden telah melakukan pembelian online sebanyak 2 kali atau lebih . Metode pengumpulan data dilakukan dengan jalan melakukan observasi, telaah dokumen dan penyebaran kuisioner. Variabel dan indikator dalam penelitian ini adalah sebagai berikut :

Tabel 3.1 Variabel dan indikator penelitian

\begin{tabular}{|l|l|}
\hline \multicolumn{1}{|c|}{ Variabel } & Indikator \\
\hline Harga & $\begin{array}{l}\text { Keterjangkauan harga, kesesuaian dengan kualitas produk, daya } \\
\text { saing harga, kesesuaian dengan manfaat, harga memengaruhi } \\
\text { daya beli konsumen, Harga bisa memengaruhi konsumen dalam } \\
\text { mengambil keputusan (Kottler 2008) }\end{array}$ \\
\hline Kemudahan & $\begin{array}{l}\text { Jelas dan mudah dimengerti, tidak membutuhkan banyak usaha, } \\
\text { sistem mudah digunakan( Venkatesh dan Davis dalam Irmandani } \\
\text { 2012) }\end{array}$ \\
\hline Kualitas Informasi & $\begin{array}{l}\text { Informasi up to date, membantu konsumen dalam membuat } \\
\text { keputusan, konsisten, mudah dipahami ( Venkatesh dan Davis } \\
\text { dalam Irmandani 2012) }\end{array}$ \\
\hline Keamanan & $\begin{array}{l}\text { Aman bertransaksi, mampu menjaga privasi, tidak } \\
\text { menyalahgunakan informasi, tidak memberikan informasi } \\
\text { konsumen ke situs lain, penjual menjaga kebocoran informasi, } \\
\text { mencegah kebocoran email pelanggan, menjaga keakurasian } \\
\text { transaksi pembayaran. (Rahadi 2013) }\end{array}$ \\
\hline Kepercayaan & $\begin{array}{l}\text { Integritas, kompetensi, konsistensi (Robbins dan Judge 2007) } \\
\text { produk, melakukan pembelian ulang (Kottler 2008) }\end{array}$ \\
\hline
\end{tabular}

\section{Hasil Dan Pembahasan}

\subsection{Untuk statistik diskriptif.}

Dari 100 responden jumlah responden laki laki sebanyak 37 (37\%) dan perempuan 63 (63\%). Media online yang banyak dipakai adalah Lazada sebanyak 23 (23\%). Dari wawancara yang dilakukan alasan menggunakan lazada karena menawarkan beberapa kelebihan diantaranya produk beragam, ada discount yang menggiurkan, metode pembayaran fleksibel.

Situs yang banyak digunakan adalah forum jual beli . Sedangkan produk fashion yang 
banyak dibeli oleh responden adalah baju sebanyak 36 (36\%), sepatu dan tas masing masing 20 (20\%), jilbab 13 (13\%) dan kosmetik sebanyak 11 (11\%). Media elektronik yang dipakai banyak yang menggunakan smartphone sebanyak 60 (60\%) karena kehidupan para mahasiswa bisa dikatakan hampir tidak pernah lepas dari smartphone. Dari 100 responden semuanya melakukan pembelian lebih dari 2 kali, bahkan 50\% dari responden melakukan pembelian lebih dari 5 kali, hal ini mengindikasikan bahwa responden sering melakukan pembelian secara online. Selanjutnya bila dilihat dari siapa yang berperan dalam pengambilan keputusan sebagian besar keputusan pembelian ditentukan oleh dirinya sendiri mengingat responden adalah mahasiswa yang masuk pada kategori usia dewasa dimana didalam mengambil suatu keputusan lebih banyak berdasarkan keinginan sendiri. Untuk Deskripsi variabel penelitian memberikan hasil sebagai berikut : Semua variabel dalam penelitian baik harga, kemudahan, kualitas informasi, keamanan dan kepercayaan yang diukur dengan indikatornya masing masing menunjukkan bahwa penilaian yang sering muncul adalah setuju, hal ini menunjukkan bahwa setiap variabel mampu dipersepsikan dengan baik oleh para responden .

\subsection{Untuk Analisis secara kuantitatif}

Untuk uji validitas semua indikator dari semua variabel memberikan hasil Nilai $r$ hitung > $r$ tabel dan nilai sig dibawah 0,05. Hal ini bisa disimpulkan bahwa semua item pertanyaan dinyatakan valid. Sementara itu untuk nilai cronbach alpha semua berada diatas nilai 0,60 sehingga bisa dikatakan reliabel. Dari hasil uji asumsi klasik, untuk uji normalitas hasil analisis plot grafik histogram menunjukkan data terdistribusi secara normal, karena datanya terlihat menyebar mengikuti garis diagonal. Untuk uji multikolinieritas semua variabel mempunyai nilai VIF $<10$ dan nilai Tolerance $>0,1$ sehingga tidak terjadi multikolinieritas. Untuk uji heteroskedastisitas dengan menggunakan scatter plot menghasilkan titik titik yang dihasilkan pada gambar menyebar dan berbentuk tidak beraturan sehingga dapat dikatakan tidak terjadi heteroskedastisitas. Hasil analisis regresi memberikan persamaan sebagai berikut :

$$
\mathrm{Y}=0,024+0,162 \mathrm{X}_{1}+0,172 \mathrm{X}_{2}+0,201 \mathrm{X}_{3}+0,311 \mathrm{X}_{4}+0,199 \mathrm{X}_{5}+e
$$

Dari persamaan diatas bisa diartikan sebagai berikut : 
Nilai Konstanta sebesar 0,024 yang berarti bahwa jika nilai dari variabel Harga $\left(\mathrm{X}_{1}\right)$, Kualitas Kemudahan $\left(\mathrm{X}_{2}\right)$, Kualitas Informasi $\left(\mathrm{X}_{3}\right)$, Keamanan $\left(\mathrm{X}_{4}\right)$, Kepercayaan $\left(\mathrm{X}_{5}\right)$ sama dengan nol, maka Keputusan Pembelian (Y) adalah sebesar 0,024 satuan.

Harga $\left(X_{1}\right)$, nilai koefisien dari variabel Harga adalah bernilai positif 0,162 yang berarti arah hubungannya positif (searah), dan hal ini berarti bahwa setiap kenaikan satu satuan variable harga, akan meningkatkan Keputusan Pembelian sebesar 0,162 satuan.

Kemudahan $\left(\mathrm{X}_{2}\right)$,nilai koefisien dari variabel Kemudahan adalah bernilai positif 0,172 yang berarti arah hubungannya adalah positif (searah), dan hal ini berarti bahwa setiap kenaikan satu satuan variable kemudahan tersebut, akan meningkatkan Keputusan Pembelian sebesar 0,172 satuan.

Kualitas Informasi $\left(\mathrm{X}_{3}\right)$, nilai koefisien dari variabel Kualitas Informasi adalah bernilai positif 0,201 yang berarti arah hubungannya positif (searah), dan hal ini berarti setiap kenaikan satu satuan variable kualitas informasi tersebut, akan meningkatkan Keputusan Pembelian sebesar 0,201 satuan

Keamanan $\left(\mathrm{X}_{4}\right)$, nilai koefisien dari variabel Keamanan informasi adalah bernilai positif 0,311 yang berarti hubungannya positif (searah) dan hal ini berarti bahwa setiap kenaikan satu satuan variable keamanan tersebut, akan meningkatkan Keputusan Pembelian sebesar 0,311 satuan

Kepercayaan $\left(\mathrm{X}_{5}\right)$, nilai koefisien dari variabel Kepercayaan adalah bernilai positif 0,199 yang berarti hubungannya positif (searah) dan hal ini berarti bahwa setiap kenaikan satu satuan variabel tersebut, akan meningkatkan Keputusan Pembelian sebesar 0,199 satuan.

Untuk uji hipotesis secara parsial memberikan hasil sebagai berikut :

Tabel hasil uji t terhadap variabel penelitian

\begin{tabular}{|c|c|}
\hline Variabel & Sig \\
\hline Harga (X1) & $\mathbf{0 , 0 4 7}$ \\
\hline Kemudahan (X2) & $\mathbf{0 , 0 1 1}$ \\
\hline Kualitas informasi (X3) & $\mathbf{0 , 0 0 5}$ \\
\hline Keamanan (X4) & $\mathbf{0 , 0 0 3}$ \\
\hline Kepercayaan (X5) & $\mathbf{0 , 0 0 9}$ \\
\hline
\end{tabular}

Pengaruh variabel Harga terhadap Keputusan Pembelian 
Hasil analisis regresi berganda menunjukkan harga berpengaruh terhadap keputusan pembelian online. Hubungan yang ditunjukkan oleh koefisien regresi bertanda positif artinya semakin sesuai harga maka keputusan pembelian secara online akan semakin meningkat . hasil ini juga sesuai dengan hasil analisis Uji t yang menguji hipotesis pertama $\left(\mathrm{H}_{1}\right)$ hasilnya menunjukkan bahwa Harga berpengaruh terhadap Keputusan Pembelian dengan melihat taraf signifikansinya yaitu sebesar 0,047. Nilai taraf signifikansi yang diperoleh adalah lebih kecil $(<)$ dari nilai $\alpha=0,05$ maka disimpulkan $\mathrm{H}_{1}$ diterima, dan ini berarti harga mempunyai pengaruh yang signifikan terhadap keputusan pembelian. Hasil ini juga sesuai dengan distribusi frekuensi jawaban responden tentang indikator indikator harga dimana dari 6 indikator dan 6 pernyataan yang menjawab setuju lebih dari $50 \%$. Hasil penelitian ini sejalan dengan penelitian sebelumnya yang dilakukan oleh Wahyu Husodo (2015), Sukawati (2018) yang menyimpulkan bahwa terdapat pengaruh yang signifikan dari Harga terhadap Keputusan Pembelian.

\section{Pengaruh variabel Kemudahan terhadap Keputusan Pembelian}

Hasil analisis regresi berganda menunjukkan ada pengaruh dari kemudahan terhadap keputusan pembelian online. Hubungan yang ditunjukkan oleh koefisien regresi adalah positif artinya semakin tinggi variabel kemudahan maka keputusan Pembelian secara online akan semakin meningkat, artinya semakin banyak kemudahan yang diberikan membuat konsumen merasa senang dan mendorong untuk melakukan pembelian. Hasil ini juga dapat dilihat dari distribusi frekuensi jawaban responden tentang 3 indikator dan 3 pernyataan variabel kemudahan yang menjawab setuju lebih dari $50 \%$.

Pada analisis Uji t terhadap hipotesis kedua $\left(\mathrm{H}_{2}\right)$ menunjukkan bahwa nilai taraf signifikansinya sebesar 0,011. Nilai taraf signifikansi yang diperoleh adalah lebih kecil (< ) dari nilai $\alpha=0,05$ maka disimpulkan bahwa kemudahan mempunyai pengaruh yang signifikan terhadap keputusan pembelian.

Hasil penelitian ini sejalan dengan penelitian sebelumnya yang dilakukan oleh Ismail Hidayat, Rois Arifin dan A Agus Priyono (2017), Hendra Gunawan dan Kartika Ayuningtyas (2018), Hamni Fadlilah Nasution (2018) yang menyimpulkan bahwa kemudahan berpengaruh terhadap keputusan pembelian.

\section{Pengaruh variabel Kualitas Informasi terhadap Keputusan Pembelian online}

Hasil analisis regresi berganda menunjukkan ada pengaruh dari kualitas informasi 
terhadap keputusan pembelian online. Hubungan yang ditunjukkan oleh koefisien regresi adalah positif artinya semakin tinggi variabel kualitas informasi maka keputusan Pembelian secara online akan semakin meningkat artinya semakin berkualitas informasi yang diberikan membuat konsumen merasa senang dan mendorong untuk melakukan pembelian. Hasil ini juga dapat dilihat dari distribusi frekuensi jawaban responden tentang 4 indikator dan 4 pernyataan kualitas informasi yang menjawab setuju diatas $40 \%$ bahkan pada indikator pertama dan keempat nilainya diatas $60 \%$.

Pada analisis Uji t terhadap hipotesis ketiga $\left(\mathrm{H}_{3}\right)$ menunjukkan bahwa nilai taraf signifikansinya sebesar 0,005. Nilai taraf signifikansi yang diperoleh adalah lebih kecil (< ) dari nilai $\alpha=0,05$. Kesimpulan yang bisa diambil adalah hipotesis ketiga $\left(\mathrm{H}_{3}\right)$ diterima, bahwa kualitas informasi berpengaruh signifikan terhadap keputusan pembelian. Hasil penelitian ini sejalan dengan penelitian sebelumnya yang dilakukan oleh Ismail Hidayat, Rois Arifin dan A Agus Priyono (2017), Dalla Noor Iftikhar dan Rizal Hari Magnadi (2017), Hendra Gunawan dan Kartika Ayuningtyas (2018) yang menyatakan bahwa terdapat pengaruh yang signifikan dari Kualitas Informasi terhadap Keputusan Pembelian.

\section{Pengaruh variabel Keamanan terhadap Keputusan Pembelian online}

Hasil analisis regresi berganda menunjukkan ada pengaruh dari keamanan terhadap keputusan pembelian online. Hubungan yang ditunjukkan oleh koefisien regresi adalah positif artinya semakin tinggi variabel keamanan maka keputusan pembelian secara online akan semakin meningkat artinya semakin tinggi tingkat keamanan yang diberikan membuat konsumen merasa aman, tenang dan senang sehingga terdorong untuk melakukan pembelian. Hasil ini juga dapat dilihat dari distribusi frekuensi jawaban responden tentang 6 indikator dan 6 pernyataan tentang variabel keamanan dimana jawaban setuju lebih dari $50 \%$.

Pada analisis Uji t terhadap hipotesis ketiga $\left(\mathrm{H}_{4}\right)$ menunjukkan bahwa nilai taraf signifikansinya sebesar 0,003. Nilai taraf signifikansi yang diperoleh adalah lebih kecil $(<$ ) dari nilai $\alpha=0,05$. Kesimpulan yang bisa diambil adalah hipotesis keempat $\left(\mathrm{H}_{4}\right)$ diterima, hal ini berarti bahwa keamanan berpengaruh signifikan terhadap keputusan pembelian.

Hasil penelitian ini sejalan dengan penelitian sebelumnya yang dilakukan oleh Diyan Firmansyah (2017), Ilham Tugiono dkk (2016), Alwafi (2016), Arasu\& Viswahattan 
(2011), yang menyatakan bahwa terdapat pengaruh yang signifikan dari keamanan terhadap Keputusan Pembelian.

\section{Pengaruh variabel Kepercayaan terhadap Keputusan Pembelian online}

Hasil analisis regresi berganda menunjukkan ada pengaruh dari kepercayaan terhadap keputusan pembelian online. Hubungan yang ditunjukkan oleh koefisien regresi adalah positif artinya semakin tinggi variabel kepercayaan maka keputusan pembelian secara online akan semakin meningkat artinya semakin tinggi tingkat kepercayaan yang diberikan membuat konsumen merasa aman dan senang sehingga terdorong untuk melakukan pembelian. Hasil ini juga dapat dilihat dari distribusi frekuensi jawaban responden tentang 3 indikator dan 3 pernyataan tentang variabel kepercayaan dimana jawaban setuju lebih dari $50 \%$

Pada analisis Uji t terhadap hipotesis kelima $\left(\mathrm{H}_{5}\right)$ menunjukkan bahwa nilai taraf signifikansinya sebesar 0,009. Nilai taraf signifikansi yang diperoleh adalah lebih kecil (< ) dari nilai $\alpha=0,05$. Kesimpulan yang bisa diambil adalah hipotesis kelima $\left(\mathrm{H}_{5}\right)$ diterima, hal ini berarti bahwa kepercayaan berpengaruh signifikan terhadap keputusan pembelian.

Hasil penelitian ini sejalan dengan penelitian sebelumnya yang dilakukan oleh Sukawati (2018), Dalla Noor Iftikhar dan Rizal Magnadi (2017), YennyYuniarti (2016), Ratna Dwi Jayanti (2015) yang menyatakan bahwa terdapat pengaruh yang signifikan dari kepercayaan terhadap Keputusan Pembelian.

\section{Pengaruh Harga, Kemudahan, Kualitas Informasi, Keamanan dan Kepercayaan terhadap Keputusan Pembelian online}

Pada analisis Uji F terhadap hipotesis keenam $\left(\mathrm{H}_{6}\right)$ menunjukkan bahwa nilai taraf signifikansinya sebesar 0,000. Nilai taraf signifikansi yang diperoleh adalah lebih kecil (< ) dari nilai $\alpha=0,05$. Kesimpulan yang bisa diambil adalah hipotesis keenam $\left(\mathrm{H}_{6}\right)$ diterima, hal ini berarti bahwa Harga, kemudahan, kualitas informasi, keamanan dan kepercayaan berpengaruh terhadap keputusan pembelian. Kesimpulan ini mengandung arti bahwa pada harga yang sesuai, kemudahan yang diberikan, kualitas informasi yang bagus, keamanan dan kepercayaan yang tinggi akan memengaruhi keputusan pembelian.

\section{Kesimpulan}

Berdasarkan hasil analisis dan pembahasan yang telah dijelaskan maka dapat disimpulkan 
sebagai berikut:

1. Dari hasil analisis data yang telah dilakukan dengan menggunakan regresi berganda beserta uji hipotesisnya dengan menggunakan uji t menunjukkan bahwa ada pengaruh harga terhadap keputusan pembelian

2. Dari hasil analisis data yang telah dilakukan dengan menggunakan regresi berganda beserta uji hipotesisnya dengan menggunakan uji t menunjukkan bahwa ada pengaruh kemudahan terhadap keputusan pembelian.

3. Dari hasil analisis data yang telah dilakukan dengan menggunakan regresi berganda beserta uji hipotesisnya dengan menggunakan uji t menunjukkan bahwa ada pengaruh kualitas informasi terhadap keputusan pembelian.

4. Dari hasil analisis data yang telah dilakukan dengan menggunakan regresi berganda beserta uji hipotesisnya dengan menggunakan uji t menunjukkan bahwa ada pengaruh keamanan terhadap keputusan pembelian.

5. Dari hasil analisis data yang telah dilakukan dengan menggunakan regresi berganda beserta uji hipotesisnya dengan menggunakan uji t menunjukkan bahwa ada pengaruh kepercayaan terhadap keputusan pembelian.

6. Dari hasil analisis data yang telah dilakukan dengan menggunakan regresi berganda beserta uji hipotesisnya dengan menggunakan uji t menunjukkan bahwa ada pengaruh kepercayaan terhadap keputusan pembelian

7. Dari hasil analisis data yang telah dilakukan dengan menggunakan regresi berganda beserta uji hipotesisnya dengan menggunakan uji F menunjukkan bahwa ada pengaruh antara harga, kemudahan, kualitas informasi, keamanan dan kepercayaan terhadap keputusan pembelian.

\section{Saran}

1. Bagi peneliti selanjutnya, sebaiknya kuisioner yang disebar menggunakan teknologi melalui kuisioner dengan link.bit.ly agar lebih efisien waktu dan paperless.

2. Bagi peneliti selanjutnya bisa menambahkan variabel lain, misalnya kualitas produk ataupun menggunakan variabel sebagai intervening .

\section{DAFTAR PUSTAKA}

AlWafi. 2011. Pengaruh Persepsi Keamanan, Kemudahan Bertransaksi, Kepercayaan 
Terhadap Toko dan Pengalaman Berbelanja Terhadap Minat Beli Secara Online Pada Situs Jual beli Tokopedia.Com. Diponegoro Journal of Management, Volume 5 Nomor 2011:Pp 134-148

Anggraeni, Penia., Madiwati, Putu, Nina. 2016. Pengaruh Kepercayaan dan Kualitas Informasi Terhadap Keputusan Pembelian Secara Online pada situs www.Traveloka.com. E-Proceeding of Management : Vol.3, No 2 (2)

Antarwiyati, P., Agus, L.N., dan Hadri, K. 2010. Determinan Electronic Loyalty (eLoyalty) Pada Website", Jurnal Akuntansi \& Auditing Indonesia, 14 (1).

Dalla Noor Iftikhar, dan Rizal Hadi Magnadi. 2017. Pengaruh Persepsi Jaminan Produk dan Kualitas Informasi Terhadap Kepercayaan Kepada Perusahaan dan Implikasinya Terhadap Minat beli di E-Commerce (Studi Bukalapak.Com) Diponegoro Journal of Management, Volume 6 Nomer 3;1-10.

Dian Firmansyah.2017. Pengaruh Pengalaman Reputasi Privasi dan Keamanan Terhadap Kepercayaan Pengguna Internet Dalam Melakukan Jual Beli Online .Skripsi, Jurnal Riset Manajemen dan Akuntansi Program Universitas Muhamadiyah Surakarta.

Fandi Tjiptono.2011. Pemasaran Jasa. Malang.Bayumedia

Ilham Tugiyono dkk.2016. Pengaruh Relathionship Marketing, Keamanan, kepercayaan dan Kualitas Pelayanan terhadap Keputusan Pembelian Online Shop dan Loyalitas Konsumen Sebagai Variabel Intervening (Studi Kasus Pada Online Shop “ NUMIRA” Semarang. Journal of Management. Volume 2 No 2 Maret 2016.

Imam Ghozali. 2014. Structural Equation Modeling Metode Alternatif Dengan Partial Least Square (PLS). Semarang : Badan Penerbit Universitas Diponegoro Semarang Irmandhani. 2012. Pengaruh Presepsi Kebermanfaatan, Presepsi Kemudahan Penggunaan dan Computer Self Efficacy Terhadap Penggunaan Online Banking Pada Mahasiswa Fakultas Ekonomi Universitas Negeri Yogyakarta. Jurnal Universitas Negeri Yogyakarta Vol 1 (3) :1-20

Industri, 2016. Jakarta, Menkominfo Ungkap nilai transaksi e-commerce capai Rp. 30 triliun per tahun. http://www.industry.co.id/read/26928/menkominfo-ungkap-nilaitransaksi-e-commerce-capai-rp30-triliun-per-tahun

Ismail Hidayat dkk, 2017. Pengaruh kepercayaan, Kemudahan, Harga Dan Kualitas Informasi Penggunaan E-Commerce Terhadap keputusan Pembelian Secara Online 
$\underline{\text { Pada Situs Bukalapak.Com (Studi Pada Mahasiswa S1 FakultasEkonomi Unisma }}$ Angkatan 2013. E journal Rset Manajemen Prodi Manajemen Fakultas Ekonomi Unisma, Vol $6(3): 64-78$

Jarvenpaa, S. L., Tractinsky, N., and Vitale, M. (2000), “Consumer Trust in an Internet Store," Information Technology and Management, 1, 45-71.

Hendra Gunawan dan Kartika Ayuningtyas. 2018.Pengaruh Kepercayaan, Kemudahan dan Kualitas Informasi Terhadap Keputusan Pembelian daring di Aplikasi Bukalapak Pada Mahasiswa Politeknik Negeri Batam. Journal of Applied Bussines Administration Vol 2 No 1 Maret 2018 hal 152-165

Kotler, Philip, dan Kevin Lane Keller, 2006, Marketing Manajemen (Manajemen Pemasaran Edisi 12). Jakarta : PT. Indeks

Kotler, Philip. 2008 Manajemen Pemasaran Analisis Perencanaan, Implementasi dan Pengendalian. Edisi 12. Jilid 1. Jakarta : Penerjemah Herujati Purwoko : Erlangga

Kotler, Philip, dan Kevin Lane Keller. 2009. Manajemen Pemasaran Jilid 1, edisi Ketiga Belas, Terjemahan Bob Sabran, MM. Jakarta: Penerbit Erlangga.

Kotler, Philip, dan Kevin Lane Keller. 2009. Manajemen Pemasaran Jilid 2, edisi Ketiga Belas, Terjemahan Bob Sabran, MM. Jakarta: Penerbit Erlangga.

Kotler, Philip.2011. Manajemen Pemasaran di Indonesia : Analisis, Perencanaan, Implementasi dan Pengendalian. Jakarta: Salemba Empat

Kotler, Phillip dan Gary Amstrong. 2001. Prinsip-Prinsip Pemasaran, jilid 2, edisi ke-8, Jakarta : Penerbit Erlangga

Luthfiya, J.2014. Pengaruh Pemasaran Online Terhadap Keputusan Pembelian Pada Siswa/I SMA Yayasan Pendidikan Harapan 3 Medan. Skripsi. Universitas Sumatera Utara.

Park, Chung-Hoon., and Young-Gul Kim., 2006, The Effect of Information Satisfaction and Relational Benefit on Consumer Online Site Commitments. Journal of Electronic Commerce in Organization , 4(1), hal.70-90

Rahadi, D.R. 2013. Pengaruh Karateristik Website Terhadap Kepuasan Pelanggan, Jurnal Manajemen dan Binis, Vol. 5(7): 20-25.

Ranganathan, C. Dan Jha, Sanjeev.2007. Examining Online Purchase Intentions in B2C EComerce : Testing an Integrated Model. Information Resources Management 
Journal, Vol 20(4), pp.48-64.

Raman, Arasu., dan Viswanathan, A. 2011. Web Services and e-shopping Decision : A Study on Malaysian e-consumer, IJCA Spesial Issue on : Wireless Information Networks dan Business Information System, 54-60

Ratna Dwi Jayanti. 2015. Pengaruh Hargadan Kepercayaan Terhadap Keputusan Pembelian Secara Online (Studi kasus Pada Harapan Maulina Hijab Jombang. Jurnal EKSIS Vol X No 1.ISSN 1907-7513 .hal 14-25.

Robbins, Stephen P. dan Timothy A. Judge. 2007. Organizational Behavior. New York: Prentice-Hall Jersey

Sukawati.2018. Pengaruh Kepercayaan, Harga, dan Kualitas Produk Terhadap Keputusan Pembelian melalui Internet Di Kota Makasar. Phinisi Integration Review, Vol I No 2 Agustus 2018. Halaman 190-200

Sugiyono. 2005. Memahami Penelitian Kualitatif. Bandung: Alfabeta

Tirto.2017.Jakarta. Profil Konsumen Belanja online di Indonesia. https://tirto.id/profilkonsumen-belanja-online-di-Indonesia-cuEG

Tribunnews.2016.Jakarta,Transaksi e-commerce di Indonesia pada 2016 Mencapai \$489 miliar http://www.tribunnews.com/bisnis/2017/02/20/transaksi-e-commrece-diindonesia-pada-2016-mencapai-489-miliar-dolar-as

Wahyu Husodo.2015. Pengaruh Kepercayaan, Kemudahan, Harga dan Kualitas Informasi terhadap Keputusan Pembelian Secara Online (Studi Pada situs OLX.co.id). Jurnal Manajemen dan Bisnis, Vol 11 No 2C .P ISSN : 0216-938x, e ISSN : 2684-8414.

Yeni Yuniarti. 2016.Pengaruh Kualitas Produk, Harga dan Kepercayaan Terhadap Keputusan Pembelian Produk Fashion. Jurnal Penelitian Universitas Jambi Seri Humaniora, Volume 18 Nomer 1 Hal 27-37. 